\title{
Prospects of multipurpose and complex use of the most important types of non-metals in the economy of the Far East region
}

\author{
Galina Sklyarova ${ }^{1 *}$ \\ ${ }^{1}$ Mining Institute of Far eastern branch of Russian Academy of Sciences, Khabarovsk, Russia
}

\begin{abstract}
The strategic importance of non-metallic minerals is determined by their large-scale and multipurpose use in the main basic complexes of the economy. The Long-Term National Program of the Russian Federation planned the study and assessment of subsoil in the field of nonmetallic minerals funding by the federal budget for four major groups of raw materials: agrochemical, non-metallic for metallurgy, environmentally friendly and construction materials. At the territory of the Far East there are geological and economic potential to create raw material bases for development of important economic complexes such as agrochemical (for fertilizer production: phosphoric - apatites, phosphates, potassium - alunites, organic - peat, sapropels; using as structure formers and soilaggregate stabilizers: carbonate rocks, natural adsorbents, organic raw materials.), metallurgical (refractory clays, alumina slates, alunits), ecological ( natural adsorbents-zeolites, bentonites, perlites, diatomites) as well as others - chemical-forestry, mineral-construction, high technologies. Positive results of geological and economic assessments of deposit prognostic models of non-metallic raw materials allow to recommend them as the objects for industrial use. It is recommended to create new mineral non-metal bases not far from the main consumers, which is the most important for remote regions of the Far East. Key words: non-metallic minerals, the Far Eastern region, industrial complexes: agrochemical, metallurgical, ecological, mineral-building.
\end{abstract}

Non-metallic mineral group is one of the most abundant natural groups, including more than 150 types of mineral raw materials. They include rock and mineral formations, from which it is technically possible and economically expedient to obtain intermediate products. In the Far East region the most important of them are: alunites, apatites, phosphates, highalumina types of materials (andalusite, dysthene-sillimanite slates), carbonate rocks, zeolites, mineral-construction and other common rocks, their practical and strategic importance is determined by large-scale and complex application.

The main text content is presented mainly by the characteristics of specific non-metals of the Far East region considering the prospects of their traditional and non-traditional use in the development of the most important industrial complexes of the economy: agrochemical, metallurgical (refractory), ecological, etc.

\footnotetext{
* Corresponding author: adm@igd.khv.ru
} 
Zoning for the main types of non-metallic raw materials was carried out for the purpose of an innovative approach to the subsoil use and planning at the stages of geological study and development of subsoil in the Far East region, it was based on the principles of rational and integrated subsoil use in view of the modern technologies of complex mineral processing.

For territories ranking with allocation of prospects and ore areas, the following factors were used: peculiarities of geographical and economic situation, the scope of productive formations development, the size of reserves and forecast resources, a degree of their development and study, industrial significance and their prospects for development in the near future. A brief description of the ore districts is given as an example.

Specific non-metals of the Russian Far East Alunites. The Far East is the only region of unique alunite mineralization in Russia. In the region, more than 100 large alunitebearing deposits and occurrences (more than 60 million tons - 5 billion tons) have been discovered. Alunite occurrences are mostly developed in the Khabarovsky Krai within the volcanic zones of the Lower- and Middle-Amur part of the Sikhote-Alin volcanic belt, in the Okhotsk district within the Ulya metallogenic zone. Alunites are hydrothermalmetasomatic formations, containing mineral alunite $-\mathrm{K}_{3} \mathrm{NaAl}_{3}\left[\left(\mathrm{SO}_{4}\right)_{2}(\mathrm{OH})_{6}\right]$, the theoretical composition of it (\%) is: $\mathrm{Al}_{2} \mathrm{O}_{3}-36.93 ; \mathrm{SO}_{3}-38.66 ; \mathrm{K}_{2} \mathrm{O}-11.37 ; \mathrm{H}_{2} \mathrm{O}-13.04$. The rocks containing more than $30 \%$ of alunite can be attributed to commercial (ore with the alunite content more than $34 \%$ can be processed without concentration). Presence of considerable amounts of aluminium, potassium and sulfur oxides in chemical composition of alunite define this type of raw material as complex, multipurpose, perspective for metallurgical, agro-industrial, ecological, mineral-construction manufacturing complexes.

In the metallurgical complex alunites can be used as refractory raw materials for alumina production. The alunites of Zagliksky deposit at Kirovobad aluminum plant (at present Gandja Alumina Plant, the Azerbaijan SSR) were used for the first time in the world practice as natural mineral raw material in the production of alumina (aluminum oxide). The alunite content in ore processing concentrates should be not less than $50-$ $70 \%$. Concentration of alunite ores, alumina production, requiring a high degree of ore grinding, application of thermal dehydration is very expensive, power-intensive production requiring the complex infrastructure development. Regarding geological and raw materials aspect the aluminium production is expedient on the basis of alunite deposits in the LowerAmur region. However, due to the lack of power base, expensive technical equipment, the alumina production in the Far East is not planned for the near future. Industrial production of aluminium from alunite ores is technologically complicated, energy-intensive production, which requires higher costs for the industrial base development. This problem for the Far East can be resolved only at the federal level in the long run.

Agro-industrial and ecological complexes: alunites - as raw material for production of potassium sulfate, aluminium sulphate. Potassium is one of the main microelements for agricultural plants. Potassium salts are the main raw material source for potassium fertilizers, their significant reserves are concentrated in the Western regions of Russia. The Far East is the most important producer of soybeans, which requires potassium sulphate fertilizer meal, complex fertilizers, therefore, the assessment and development of alternative raw material sources for potassium production is of vital economic value. The VAMI's (the Russian Aluminium Magnesium Institute) technological researches of alunite ores of the Far East developed the simplified schemes of their processing without preliminary very intensive process of ore fine grinding and obtaining after their concentration very scarce aluminium sulphate and alum, in which the whole alumina as well as sulfate potassium will be binding. Sulfate aluminum is widely used as a coagulant for drinking and sewage treatment, in pulp and paper, textile and other industries. Potassium sulfate is a valuable potassium chlorine-free fertilizer, and alum is also widely used. 
Mineral-construction complex. The complex raw materials for manufacturing many types of industrial products can be not only alunite ore, but also in general, the rocks enclosing them: monoquartzites - glass, ceramic and decorative-facing; rutile quartzites titanium, ceramic and decorative-facing; sulfuric quartzites - sulfuric and ceramic; alunite quartzites - aluminous, sulphuric-acid, potassium, ceramic, cement, brick, and sometimes recovering gold as byproduct, silver-diaspore quartzites - alumina and quartz raw materials; kaolin quartzites - ceramic, recovering gold as byproduct, silver; sericite quartzites alumina potash and quartz raw materials; propilites - a possible source of non-ferrous and precious metals. Besides, in alunite concentrates gold is defined in amounts of 0.4-0.7 g/t, silver - 2.8-3.1 g/t, in tails, 0.9-1.1 g/t , 3.8-4.4 g/t, respectively. To extract precious metals, the crushed ore prepared for flotation was subjected to cyanidation. $98 \%$ of gold and about $63-83 \%$ of silver were extracted when the cyanide of potassium $0.64 \mathrm{~kg} / \mathrm{t}$, lime $3.7 \mathrm{~kg} / \mathrm{t}$ were used during the cyanidation time of 8 hours. Heap method of cyanidation allows to process several million tons of ore that allows to extract these metals from ores also.

In general, geological and economic prerequisites of economic complex development of alunite ore deposits are prospective for further development of the Russian Far East economy. The innovative technological processes of alunite raw materials development in the Far East include research-practical works (VAMI, DVIMS (Far Eastern Institute of Mineral Resources), etc.), innovations in technology of alunite ore processing with alumina, sulphate aluminium (coagulant), potassium sulphate (potassium fertilizer) and other midproducts.

Anortozites are complex raw materials for apatite-ilmenite-titanomagnetite and aluminous mineralization. One of the largest in the world the East Asian anorthosite belt was identified at the territory of the Far East.

Apatite-titanium raw materials. In the BAM (Baikal-Amur Mainline) region within the Stanovaya fold-block system, the Dzhugdzhurskaya, Chogarskaya and Baladekskaya structural-mineragenic zones (the Khabarovsky Krai), as well as in the Amur region KalaroHaninskiy ore district with deposits of complex apatite-ilmenite-titanomagnetite and apatite-ilmenite ores, are differentiated, their estimated resources are very significant (Ti$\mathrm{O}_{2} / \mathrm{P}_{2} \mathrm{O}_{5} \mathrm{mln} \mathrm{t}$ ): Gayumskoe-23.3/7.6, Bogide-79.8/68.4, Yaninskoe - 70.8/46.4. The technological tests show that complex apatite-titanium ores are most effectively processed by magnetic-flotation scheme, which includes the allocation of titanium-magnetite concentrate by wet magnetic and electromagnetic separation and subsequent flotation of apatite and ilmenite from non-magnetic fraction. Positive results of geological - economic estimation of the predicative models of these deposits allow to consider them as the priority objects for detailed geological and technological studies for assessment of prospects of raw material base for production of phosphoric fertilizers and iron-titanium concentrates for ferrous and non-ferrous metallurgy on the basis of the most prospective deposits of complex apatitetitano-magnetite mineralization in the composition of anortoxite formations.

In the Amur Oblast (District) OOO Uralmining was granted the right to use subsoil (until 2030) for the purpose of exploration and production of titanium-magnetite ores at the Bolshoy Seyim deposit, located at the Tyndinsky district territory, $15 \mathrm{~km}$ northeast of the $\mathrm{BAM}$ railway line. The $\mathrm{P} 1$ prognostic resources of the deposit were tested as 36 million tons of TiO2. According to the preliminary project of this deposit development (1998), the construction of mining-processing complex (GOK) and plant for pigmented titanium dioxide production was envisaged.

Alumina raw materials. The anorthosites are characterized by high alumina content up to $26-30 \%$ and bases (predominantly calcium monoxide) - up to $10.8 \%$, silica - up to $53 \%$, iron oxide - less than $4 \%$, sodium and potassium oxides $-5.2 \%$. The requirements for anorthosites as alumina raw material were not developed. In the 1980s, VAMI (the AllUnion Aluminum-Magnesium Institute) performed technological testing for the complex 
processing of Canadian anorthosites with alumina content of about $27 \%$. As a result it has been established that they can be processed for alumina by baking anorthosites with limestone and soda. The forecast resources of anorthosite raw materials of the Far East are determined as 800 bln $\mathrm{t}$ (up to $30 \mathrm{~m}$ depth). However, almost all of them are located in remote regions, far from the BAM. Only Kavaktinskiy (30 km from BAM), Koloktikanskiy (35 km from the Far East Railroad) and Selemdzhinskiy (60 km from BAM) with total reserves of about 1.5 bln $t$ can be offered for practical estimation. Technological possibilities of anorthosite and leucite raw materials use were studied only at a trial and experimental-factory levels.

High-alumina refractory raw materials. Alternative types of non-traditional refractory raw materials are represented by such minerals as high-alumina rocks containing minerals of sillimanite, disthen, andalusite group; alunites, anorthozites and also zirconiumcontaining rocks, by preliminary qualitative and quantitative characteristics satisfying the requirements for using as refractory raw materials. [6-7, 9].

In the south of the Far East the ore-bearing formations, prospective for high-alumina raw materials (andalusite-disthen-sillimanite with average content of 20-40\%) in the composition of ancient metamorphic masses, are well represented. About 100 deposits and occurrences were registered, for 23 of them total forecast resources in the amount of about 8,958 million tons were estimated, this confirms the huge potential of the territory for these types of high-alumina raw materials. At present, in metallurgy the open-hearth process is replaced by steel making in converters and electric furnaces that will involve usage of more high-resistant types of refractory raw materials. In foreign countries, non-traditional types of refractory raw materials containing such alumina minerals as kyanite, andalusite, sillimanite, as well as zirconium-containing minerals, are extracted and used for modern metallurgy, growth tendency of their demand is marked. The Algaminskoe deposit of zirconiumcontaining ores with reserves of about 215 thousand tons was prospected, its development can be commercial. For estimation of economic significance of the areas of high-alumina and zircoium-containig formations development, it is necessary to carry out exploration and estimation.

\section{Adsorbent Materials}

The interest to use natural mineral adsorbents as raw materials for protection and rehabilitation of environment increases due to growing importance of the environmental problems.

The Far East of Russia has a significant raw material base of various mineral-industrial types of natural adsorbents. Traditionally they are: zeolitolites, opal-kristabolite rocks (opokas, diatomites, tripolites), bentonite and palygorskite clay, vermiculite, perlite. The rocks with active constituents content more than $70 \%$ are attributed to the high-quality adsorbents for the most types of natural adsorbents. In addition, experimental technological research has established the possibility to obtain commercial products with adsorption properties from alunite (sulfate aluminum), brucite (brucite-zeolite product). In modern conditions the study and development of significant raw material potential of natural adsorbents of the Far East is very important for consumption and production growth of highactive adsorption-filter materials for industrial and environmental aims.

\section{Fluorite}

Fluorite $\left(\mathrm{CaF}_{2}\right)$ is used as fluxes in metallurgy, as well as in hydrofluoric acid, freon for laser equipment manufacture. The unique properties of fluorite and its wide use in the industry are associated with a low melting point $\left(1270^{\circ}\right)$ and high chemical activity of fluorine, with the highest electro-negativity. In Russia, fluorite is one of the traditionally scarce material. To reduce import and improve the structure of fluorite reserves, it is necessary to accelerate the development of the identified sites with the balance reserves of Voznesensky 
and Pogranichny deposits in the Primorsky Krai, Preobrazhenovsky deposit in the Jewish Autonomous Oblast (JAO).

In Primorsky Krai ZFO GKHK Bor Enterprise with full technological cycle, is carrying out development (since 1959) of Dalnegorsky deposit with extraction of boron ores (reserves of them are up to $86.6 \%$ from stocks of $\mathrm{B}_{2} \mathrm{O}_{3}$ of the Russian Federation), also datolite ores and limestone, datolite ores processing, chemical processing of datolite concentrate. The enterprise consists of a mine (two quarries), a concentrating factory of boric and sulfuric acids manufacturing, a boron shop and other auxiliary shops. Two pit open mining with blasting was used. The reserves life is over 200 years. Treatment at the concentrating mill is carried out by flotation with pre-crushing up to- $0.15 \mathrm{~mm}$. The main products are: datolite concentrate, boric acid, calcium borate, boric anhydride, sulfuric acid.

\section{Brucite}

In the Far East in the JAO (ZAO Kuldursky Brucite Mine), the only in Russia brucite deposit of the same name, is developed in the open way, its average $\mathrm{MgO}$ content being 62.0-65. $0 \%$. Before entering the crushing and sorting station brucite is exposed to orepicking and large chunks cleaning of the enclosing rocks. The quality of the commodity brucite meets the requirements of TS (technical specifications) 14-8-392-82 with the allocation of 3 grades of $\mathrm{Mg}(\mathrm{OH}) 2-60-62 \%$; 4 and $5-60$ and 55\% (off-balance). The content of the grades should be respectively, \%: $\mathrm{CaO}-1.5-4.0, \mathrm{SiO}_{2}-1.5-8.0, \mathrm{Fe}_{2} \mathrm{O}_{3}-0.15-1.0$. The commercial product is used by OAO Ogneupory (Refractories) to obtain electrical periclase and spinel powders. OAO Ogneupory Trade Company (Yekaterinburg) is the official trade representative of the mine.

Only in Yakutia, the Olekminskoe deposit of gypsum is being developed (gypsum stone which is supplied for cement production) and common chloride. 5 deposits are explored, four of them represented by rock salts and one - by salt brine. The deposits are known as a part of the halogen Cambrian strata, with thickness of $8-47 \mathrm{~m}$ with salt saturation from 82 to $100 \%$.

\section{Agrochemical Raw Materials}

The analysis of regularities of mineral base formation for agrochemical complex of the Far East Federal District is made for estimation of the prospects of their application in agriculture [1-5]. Within the region there are found practically implemented or estimated minerals as a result of agronomic studies, they are raw materials for fertilizer production (phosphoric fertilizers - apatites, phosphorites; organic - peat, sapropels; potassium - alunites), soil aggregate stabilizers and chemicals for soil composition improvement, mineral fertilizers, materials for pest control (carbonate rocks, zeolites, perlites, diatomites, bentonites, vermiculites, peat, sapropels;).

In practical and experimental conditions the effective influence of natural adsorbents (minerals, rocks or their commodity products) in the processes of rehabilitation of ecological soil and water contaminated with radionuclides, hazardous and poisoned substances was established. Adsorbents are high-dispersed artificial or natural substances characterized by specific chemical properties [8].

It is considered to refer to natural adsorbents the rocks, the structural minerals of which have high adsorption, ion, catalytic filtering and structural properties of selective absorption of some components from the adjacent gas or solution environments. They are traditionally: zeolitolites, opal-kristabolite rocks (opokas, diatomites, tripolites), bentonite and palygorskite clays, vermiculite, perlite [10-11]. For most types of natural adsorbents, the rocks with active components content being more than $70 \%$ are attributed to high-quality rocks. Furthermore, experimental technological research showed the possibility to obtain commercial products with adsorption properties from alunite (sulfate aluminum), brucites 
(brucite-zeolite product). The adsorbent properties of natural minerals are not uniform due to the differences of crystalline structures and chemical composition.

Thus, at the territory of the Far East there are prerequisites for creation and development of raw material bases for agrochemical (fertilizers production: phosphoric - apatites, phosphorites, potassium - alunites, organic - peat, sapropels, soil aggregate stabilizers and chemicals for amendment of soils composition - carbonate rocks, natural adsorbents), metallurgical (refractory), ecological (adsorbent) and other regional complexes of economy. The positive results of the geological and economic assessment of the prognostic models of these mineral deposits allow to consider them as the priority objects for the development of detailed geological and technological researches [12]. Due to remoteness from processing agrochemical companies of Russia, climatic and natural conditions of "risky agriculture", the strategy of agriculture development in the Far East should aimed at development of local agrochemical material sources, the prospects of which are very significant.

\section{References}

1. E.M. Aksenov, N.G. Vasiliev, Rudy i Metally. 1. 5-6. (2009) (In Russ.)

2. G. F. Sklyarova, Mineralno-syrjevoy sektor nemetallov Dalnego Vostoka i ego rol dlya ekonomiki regiona Khabarovsk. 287. (2013) (In Russ.)

3. R.K. Sadykov, R.M. Minulin, Razv. i Okhrana Nedr. 3. 3-5. (2009) (In Russ.)

4. I. Yu. Rasskazov, G. F. Sklyarova, A.P. Van-Van-E, Problems of Compl. Developm. of Geores., Mater. of V All-Russ. Scienc. Conf. Thirt. Anniv. of Min.Inst., FEB RAS, 428441, (2013) (In Russ.)

5. A. F. Karpuzov, A. V. Tarasov, Min. Res. of Russ. Econ. and Manag. 6. 2-12, (2015) (In Russ.)

6. G. F. Sklyarova, Novye Ogneupory (New Refractories), 1, 6-13. (2014). (In Russ.)

7. G. F. Sklyarova, Otechestv. Geolog. 3. 3-7, (2012)

8. V.A. Buryak, V.Ya. Bespalov. et al, Novy Geologo-Promyshl. Tip Zirkon Oredenenie (New Geol.- Industr. Type of Zircon Mineraliz.) 216, (1999) (in Russ.)

9. G. F. Sklyarova, V. E. Kislyakov, Mod. Techn. of Min. Res. Devel., Deutschland, Saarbrucken: LAP LAMBERT Acad. Publ. ,120-123, (2012)

10. I. Dwyer. Zeolite structure composition and catalysis, Chem. and Ind., 7, 258-269, (1984)

11. T.S. Lovering, Epigenetic, diplogenetic, singenetic and lithogene deposits, Econ.Geol. 58, 5 (1963)

12. A. Alietti, Polimorfism and cristalchemistry of heularites and clinoptilolites, Amer. Miner., 57 (9-10). 1448-1462, (1972). 